\title{
Ethnologies
}

\section{Christa J. Jones and Claudia Schwabe (eds.). New Approaches to Teaching Folk and Fairy Tales. (Logan, UT: 2016, Utah State University Press. Pp. 252, ISBN 978-1-60732-480-5.)}

\section{Lori Elias}

Volume 37, numéro 2, 2015

URI : https://id.erudit.org/iderudit/1041497ar

DOI : https://doi.org/10.7202/1041497ar

Aller au sommaire du numéro

Éditeur(s)

Association Canadienne d'Ethnologie et de Folklore

ISSN

1481-5974 (imprimé)

1708-0401 (numérique)

Découvrir la revue

Citer ce compte rendu

Elias, L. (2015). Compte rendu de [Christa J. Jones and Claudia Schwabe (eds.). New Approaches to Teaching Folk and Fairy Tales. (Logan, UT: 2016, Utah State University Press. Pp. 252, ISBN 978-1-60732-480-5.)]. Ethnologies, 37(2), 215-217. https://doi.org/10.7202/1041497ar d'utilisation que vous pouvez consulter en ligne. 
Christa J. Jones and Claudia Schwabe (eds.). New Approaches to Teaching Folk and Fairy Tales. (Logan, UT: 2016, Utah State University Press. Pp. 252, ISBN 978-1-60732-480-5.)

New Approaches to Teaching Folk and Fairy Tales, edited by Christa C. Jones and Claudia Schwabe, is a compilation of teaching strategies utilized by college professors, authors and lecturers primarily from Canada and the United States, but also including France, Portugal and Switzerland. While primarily geared for instructors in higher education, teachers of advanced secondary school literature courses and folk studies units might also glean useful educational processes from its collection.

Certainly there are those outside of the genre who might think of fairy tales as a medium solely for children and animated musicals; for those individuals, this book - and the work of its contributors - make it abundantly clear that fairy tales are far more than "kiddie lit." As mentioned by a number of the book's contributors, for centuries fairy tales have been utilized by cultures across the globe to teach morality, as well as in more recent years, to hold a mirror to the mores of each story's time and place, including views on gender equality (or inequality), personal relationships, facing the challenges of life (using often extraordinary situations to illustrate ordinary trials), and class structure. Also, more contemporary "fairy tales" have made their way into contemporary popular culture, with the success of book and film franchises such as the Harry Potter and The Lord of the Rings series, and the films of the Disney Renaissance (beginning in 1989 with The Little Mermaid, based on the fairy tale by Hans Christian Andersen). And as the editors mention in the book's introduction, in France fairy tales were typically embraced by aristocratic women as a sort of manual to the expectations of life at court.

Following a forward by David Haase, Wayne State University professor of German, and the aforementioned introduction - where the editors make a strong case for interdisciplinary teaching in regard to folk tales - the book is divided into four sections. The first, Fantastic Environments: Mapping Fairy Tales, Folklore, and the Other World, looks at syllabi from coursework at Harvard University (Christine Phillips Mattson and Maria Tatar), Utah State University (Lisa Gabbert) and Cardiff University (Juliette Wood). While drawing from different populations and presented in various contexts -a full-length undergraduate course encompassing a variety of majors, a two-week overview as part of an introductory folklore class and a termlong humanities course, respectively - examining the course requirements alongside each other shows a strong similarity of approaches in teaching 
fairy tales. One of the most notable consistencies is the culminating assignment of a self-scribed fairy tale by each student, which shows that the art of the fairy tale continues to develop across time and societies.

The second section is entitled Sociopolitical and Cultural Approaches to Teaching Canonical Fairy Tales and has a farther-reaching scope, both in coursework and in the origins of the covered materials. Doris McGonagil, professor of German Studies at Utah State, examines the relationship between fairy tale characters and their natural environments, particularly the forest, which of course figures so prominently in a number of traditional stories.

Inspired by a student's discovery of fairy tale film depictions released by the former East Germany's state-owned film studio, Claudia Schwabe re-designed a course in order to view these films and examine how their versions of well-known stories (Snow White, Rumpelstiltzkin, Sleeping Beauty) could be used to promote Communist propaganda. She too has her students create their own fairy tale, but takes it a step further by requiring them to incorporate a current political or societal issue into their original stories. (This course also requires delving into the political events surrounding the creation of East Germany, as today's college students were born after the reunification of Germany).

Schwabe's colleague Christa C. Jones discusses the study of the French fairy tales of the seventeenth century, in particular those of Charles Perrault, and their relationship to the cultural mores of the seventeenth century, specifically during the reign of Louis XIV, the "Sun King." Rounding out this section of the book is Anissa Talahite-Moodley's work with Shahrazad at the University of Toronto, teaching the story not only in its own cultural context, but also getting North American students to relate to the story through their own conceptions of Islam and the Middle East.

The third section, Decoding Fairy-Tales Semantics: Analyses of Translation Issues, Linguistics, and Symbolisms, takes on a common and crucial issue in the area of transmitting stories in a genre that has far-reaching roots across national boundaries, but is also based in oral tradition. Christine A. Jones, professor of French at the University of Utah, discusses the merits of reading fairy tales in their original languages as well as their English translations, in order to explore how translations might affect how the piece is transmitted. Armando Maggi, who teaches Italian literature at the University of Chicago, has his students study fairy tales as deeply as they would heavier works, via Giambattista Basile's famed 
The Tale of Tales, as well as the Brothers Grimm's version of Basile's work in their native German, Children's and Household Tales. Cyrille Francois, a lecturer at the University of Lausanne in Switzerland, focuses on Hans Christian Andersen, whose use of "colloquial Danish," rather than a more formal style of writing, was revolutionary at the time (and certainly has North American parallels in the writings of Annie Proulx, Mark Twain and Harper Lee, among others).

As part of his undergraduate anthropology course at the Instituto Universitário de Lisboa in Portugal, Francisco Vaz da Silva has students compare and contrast three versions of the classic tale "Little Red Riding Hood": Charles Perrault's "Le Petit Chaperon rouge," the Brothers Grimm's "Rotkäppchen," and an orally-transmitted French rendition, "Histoire de la mère-grande."

The final section looks at Classical Tales Through the Gendered Lens: Cinematic Adaptations in the Traditional Classroom and Online. It should be noted that these are not the typical child-appropriate movies that might come to mind: many of the films discussed in these synopses are mature in theme, as is noted by the writers. Wayne State University's Anne E. Duggan has her classes view the work of two French film directors, François Ozon and Catherine Breillat, and the homosexual themes they explore in their respective films Criminal Lovers (based on Hansel and Gretel) and Sleeping Beauty. Pauline Greenhill and Jennifer Orme provide a thorough look at their online course regarding gender issues in films and television episodes based on fairy tales. A course description by Jeana Jorgensen of Butler University completes the book; in her class on gender studies, students study older versions of stories, view and discuss Disney adaptations of fairy tales and then look at other contemporary renditions of fairy tales, centering on their treatment of issues such as sexuality and gender.

It is clear that this collection covers a wide range of interests, genres and academic areas. It is a valuable resource for instructors in higher education who are new to the teaching of fairy tales, as well as those with experience who are looking to expand or enhance their current syllabi, particularly those who wish to teach across curricular areas.

Lori Elias 